\title{
Antimicrobial activities and phylogenetic study of bacteria associated with Cyperus rotundus rhizosphere from Cemoro Sewu Plateau, Indonesia
}

\author{
AMBARWATI AMBARWATI ${ }^{1,2, \boldsymbol{v}}$, SUBAGUS WAHYUONO ${ }^{3}$, SUKARTI MOELJOPAWIRO ${ }^{4}$, \\ LANGKAH SEMBIRING ${ }^{5}$, TRIWIBOWO YUWONO, \\ ${ }^{1}$ Faculty of Biology, Universitas Gadjah Mada. Jl. Teknika Selatan, Sleman 55281, Yogyakarta, Indonesia \\ Tel.: +62-274-580839, Fax.: +62-274-6492355, `email: ambarwati@ums.ac.id \\ ${ }^{2}$ Public Health Department, Faculty of Health Sciences, Universitas Muhammadiyah Surakarta, Central Java, Indonesia. \\ ${ }^{3}$ Laboratory of Biology Pharmacy, Faculty of Pharmacy, Universitas Gadjah Mada. J1. Sekip Utara, Sleman 55281, Yogyakarta, Indonesia \\ ${ }^{4}$ Laboratory of Biochemistry, Faculty of Biology, Universitas Gadjah Mada. J1. Teknika Selatan, Sleman 55281, Yogyakarta, Indonesia \\ ${ }^{5}$ Laboratory of Microbiology, Faculty of Biology, Universitas Gadjah Mada. J1. Teknika Selatan, Sleman 55281, Yogyakarta, Indonesia \\ ${ }^{6}$ Department of Agricultural Microbiology, Faculty of Agriculture, Universitas Gadjah Mada. Jl. Flora, Bulaksumur, Sleman 55281, Yogyakarta,

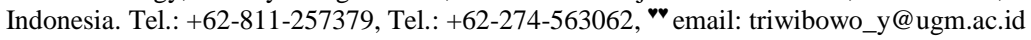

Manuscript received: 11 June 2019. Revision accepted: 20 July 2019

\begin{abstract}
Ambarwati A, Wahyuono S, Moeljopawiro S, Sembiring L, Yuwono T. 2019. Antimicrobial activities and phylogenetic study of bacteria associated with Cyperus rotundus rhizosphere from Cemoro Sewu Plateau, Indonesia. Biodiversitas 20: 2206-2212. A study has been conducted to investigate the activity of bacteria isolated from the rhizosphere of Purple Nut Sedge (Cyperus rotundus) from Cemoro Sewu Plateu, Indonesia as antimicrobial agent and the molecular relatedness between the isolates with other bacteria based on phylogenetic tree analysis. A total of six bacteria were obtained and tested for their capability to inhibit the growth of test organisms using agar block method and characterized molecularly using $16 \mathrm{~S}$ rDNA sequence analysis. It was observed that the six isolates demonstrated the ability to inhibit at least one of four test microorganisms growth, with a diameter of inhibition zone ranging from 8-35 $\mathrm{mm}$. The CRC32 isolate was the best isolate in inhibiting Staphylococcus aureus ATCC 25923 with a diameter inhibition zone of 26 $\mathrm{mm}$ (strong), while isolate CRA8 was the best anti-Candida (showing $35 \mathrm{~mm}$ of inhibition zone). The phylogenetic tree analysis resulted in two genera, four isolates belonging to Bacillus, while the other two isolates were known related to Paenibacillus genus. BLAST analysis on the CRC 32 isolate revealed that it is closely related with Paenibacillus peroriae strain 3763 with $99 \%$ sequence similarities and CRA8 isolates demonstrated the highest similarity with Paenibacillus sonchi strain X19-5 (97\%). The results of this study demonstrated that the bacterial isolates from plant rhizosphere of Cemoro Sewu Plateau were the members of the Bacillus and Paenibacillus genera and demonstrated the potential as antimicrobial agent.
\end{abstract}

Keywords: Antimicrobial, bacteria, Cyperus rotundus, phylogenetic, rhizosphere

\section{INTRODUCTION}

Microorganisms, including bacteria, are secondary sources of metabolites that contain bioactive compounds and demonstrated hemolytic and surface activities (Romanenko et al. 2008). They also showed tolerance to heavy metal and resistant to arsenic and boron (Nithya and Pandian 2010), may act as biocontrol (Mardhiana et al. 2017) also as growth-promoting factors (Zhao et al. 2018), and play a role as antibacterial, antimicrobial, and antibiotics-producing organisms. Despite the fact that Streptomyces is widely known as the most $(70-80 \%)$ antibiotic producers (Arifuzzaman et al. 2010; Ullah et al. 2010), however, the role of bacteria in producing antibiotics is also regarded as important. Based on data from ALD (Antibiotic Literature Database) Italy, among 8000 antimicrobials $16.9 \%$ is produced by bacteria (Lazzarini et al. 2000). Antibiotics produced by actinomycetes and bacteria are more desirable than antibiotics produced by fungi. Among antibiotics- producing bacteria, Pseudomonas pyacyanea and Bacillus spp. are the most interesting bacteria (Florey 1947).

Several studies have demonstrated the role of bacteria in inhibiting other microorganisms, either as antibacterial, antimicrobial, or as antibiotic producers. Bacterial isolates obtained from seahorses (Hippocampus guttulatus) collected from Galicia coast, Spain (Balcazar et al. 2010), brown algae Sargassum spp. from Panjang Island (Susilowati et al. 2015), from marine sponges at Lakshadweep Archipelago (Gopi et al. 20120, marine sponge Reniera sp from Panjang Island, Jepara (Asagabaldan et al. 2017), endophytic bacteria from seagrass from Rote Ndao, East Nusa Tenggara, Indonesia (Fitri et al. 2017) and sponges Xestospongia testudinaria from Sorong, Papua (Cita et al. 2017) have been shown to produce antibacterial substances.

Similarly, epibiotic bacteria from marine sponge Petrosia ficiformis (Chelossi et al. 2004), bacteria from marine mollusc Anadara broughtani from the sea of Japan (Romanenko et al. 2008), marine bacteria from Sydney Harbour (Wilson et al. 2010), marine bacteria in biofilms 
(Wilson et al. 2011) and sponge endosymbiotic bacteria at Agatti Island, Lakshadweep Archipelago (Mohan et al. 2016), heterotrophic bacteria from Palk Bay sediments (Nithya and Pandian 2010), bacteria isolated from saline soil (Amin et al. 2012), and from soil (Abbas et al. 2014) also showed antibacterial activity.

The previous studies have demonstrated that endophytic bacteria from the roots of Cyperus rotundus can act as biocontrol agent and suppress Meloidogyne incognita infection in tomato plants (Mardhiana et al. 2017). The study has been conducted to investigate the activity of bacteria isolated from the rhizosphere of Purple Nut Sedge (Cyperus rotundus) from Cemoro Sewu Plateau, Indonesia as antimicrobial agent and the molecular relatedness between the isolates with other bacteria based on $16 \mathrm{~S}$ rDNA sequence.

\section{MATERIALS AND METHODS}

\section{Sample collection}

The soil sample was taken from the rhizosphere of Cyperus rotundus from Cemoro Sewu plateau, Magetan district, East Java, Indonesia. The soil was collected from three sites and placed in sterile plastic. The sampling site is located at a high-altitude of 1920 meters above sea level. A total of six bacterial isolates obtained from the rhizosphere of Cyperus rotundus were then characterized.

\section{Antimicrobial activity assay}

All six bacterial isolates were then tested for their ability to inhibit the test microorganisms growth, namely: Staphylococcus aureus (S. aureus) ATCC 25923, Bacillus subtilis (B. subtilis) FNCC 0060, Escherichia coli (E. coli) ATCC 35218 and Candida albicans ( $C$. albicans). The antimicrobial assay used was agar blocks method (Nedialkova and Naidenova 2005). Bacterial isolates were grown on Nutrient Agar medium cut out with a $6 \mathrm{~mm}$ diameter cork borer. The blocks piece were then placed on Petri dishes which has been previously inoculated with test microorganisms and perforated by the same device. The bacterial isolates were cultivated at $30^{\circ} \mathrm{C}$ for $1 \times 24$ hours. Antimicrobial activity was measured based on the diameter of inhibition zone. The sterile areas, which did not show any growth, were then categorized; if the diameter of the barrier zone is $7-15 \mathrm{~mm}, 16-25 \mathrm{~mm}$, and more than 25 $\mathrm{mm}$, the inhibitory activity is categorised as weak, moderate, and strong, respectively (Nedialkova and Naidenova 2005).

\section{DNA extraction of bacterial isolates}

Bacterial isolates were grown in $20 \mathrm{ml}$ of Nutrient Broth (Oxoid) medium for seven days, followed by centrifugation at 4,000 rpm for 5 minutes. The pellets were fed to a 1.5-ml Eppendorf tube, mixed with $1 \mathrm{ml}$ of lysis buffer (100 mM tris $\mathrm{HCl} 1 \mathrm{M} \mathrm{pH} \mathrm{8,} 100 \mathrm{mM} \mathrm{NaCl}, 50 \mathrm{mM}$ EDTA pH 8, 2\% SDS) and vortexed for 2 min. Twenty $\mu 1$ of Proteinase $\mathrm{K} 20 \mathrm{mg} / \mathrm{ml}$ was added and shaken quickly for 30 minutes, followed by adding $40 \mu \mathrm{l}$ lysozyme and incubated at $55^{\circ} \mathrm{C}$ for 30 minutes in water bath (with intermittent shaking every 15 minutes). The mixture was then centrifuged at $1,3000 \mathrm{rpm}$ for $5 \mathrm{~min}$. The supernatant was decanted into 2-ml Eppendorf tube, mixed with V/V phenol and vortexed rapidly, followed by shaking fastly for $30 \mathrm{~min}$. Subsequently, the mixture was centrifuged at 1,3000 rpm for $10 \mathrm{~min}$. The supernatant was taken slowly and fed into new 2-ml Eppendorf, followed by adding (V/V) cold chloroform and shaken slowly for $20 \mathrm{~min}$, and then centrifuged at 13,000 rpm for $8 \mathrm{~min}$. The supernatant was then mixed with absolute ethanol 1: 1 and kept overnight. The next day the mixture was centrifuged at 13,000 rpm for $10 \mathrm{~min}$ and the supernatant was discarded. The pellets were washed with ethanol $70 \%$ and the ethanol was then discarded. DNA was then resuspended using 50 $\mu l$ TE buffer (10 mM Tris $\mathrm{HCl}$ pH 8, $1 \mathrm{mM}$ EDTA pH 8) and allowed to stand for 2-4 hours. If necessary, $3 \mu \mathrm{l} /$ tube of $10 \mu \mathrm{g} / \mathrm{ml}$ of RNAse can be added. DNA suspension was then stored at $-20^{\circ} \mathrm{C}$ or used directly (Magarvey et al. 2004 with some modifications). Modification of the Magarvey et al. (2004) protocol was based on the fact that the Magarvey protocol used for extraction of DNA from actinomycete which requires different growth media for actinomycete cultivation. Modification was mainly done on the use of different cell disruption method. In the case of Magarvey protocol, CTAB was used to aid in the cell breakage, while in this study, cell breakage was carried out using lysis buffer containing $2 \%$ SDS.

\section{PCR amplification of $16 \mathrm{~S}$ ribosomal RNA gene}

DNA extract of 16S rRNA gene was amplified by PCR (BIO-RAD T100 Thermal Cycler) using universal primers 27F and 1492R. The PCR mixture contains Go Taq®Green Master Mix Promega (1X final concentration) (12,5 $\mu \mathrm{l})$, $\mathrm{DDH}_{2} \mathrm{O}$ (to make final volume of $25 \mu \mathrm{l}$ ), primer $27 \mathrm{~F}$ (5 $\mu \mathrm{M})$, primer $1492 \mathrm{R}(5 \mu \mathrm{M})$, and DNA extract (100-200 $\mathrm{ng})$. The PCR reaction was carried out under the following conditions: pre-denaturation at $94^{\circ} \mathrm{C}$ for 5 minutes followed by denaturation at $94^{\circ} \mathrm{C}$ for 1 minute for 30 cycles, than annealing at $55^{\circ} \mathrm{C}$ for 1 minute, elongation at $72^{\circ} \mathrm{C}$ for 1 minute and the final elongation was done at $72^{\circ} \mathrm{C}$ for 10 minutes. The PCR products were then analyzed by agarose $1 \%$ gel electrophoresis under UV light.

\section{DNA sequencing}

DNA sequencing was carried out at First BASE Laboratories Bhd, Selangor, Malaysia. The purification of PCR product was carried out by using PCR purification KIT BigDye® Terminator v3.1 Cycle Sequencing Kit. The sequencing was conducted by using ABI PRISM 3730xl Genetic Analyzer develop by Applied Biosystems, USA. The DNA sequences result were assembled, analyzed and edited by using CAP3 software package and compared with bacteria sequences from the NCBI database. The sequences were then aligned with the available database and the sequence similarity was analyzed detected by using BLAST (Basic Local Alignment Search tool) program (Altschul et al. 1990). 


\section{Phylogenetic analysis}

The DNA sequences of six bacterial isolates were aligned with CLUSTALX multiple alignments (Thompson et al. 1997). The phylogenetic tree was constructed by using MEGA version 7 program (Kumar et al. 2016), performed by using the neighbor-joining method and validated by $1000 \mathrm{X}$ bootstrapping as described by Saitou and Nei (1987) that this method can be used to build phylogenetic tree by bootstrapping validation.

\section{RESULTS AND DISCUSSION}

\section{Purification and identification of bacterial isolates}

A total of 6 bacterial isolates were successfully isolated and purified from a soil sample of Purple Nut Sedge (Cyperus rotundus) rhizosphere from Cemoro Sewu Plateau (Figure 1). The bacterial isolates were further identified by using Gram staining procedure (Madigan et al. 2003). The results of Gram staining showed that the cell morphology of the isolates were rod-shaped bacteria, had spores and purple, this indicated that the bacterial isolates were of Gram-positive bacteria (Figure 2).

\section{Antimicrobial activity}

Screening of the ability of bacterial isolates to inhibit the growth of test microorganisms was done by agar blocks method with four test microorganisms. A total of six bacteria isolates known to inhibit at least one of four test microorganisms with a diameter of the steril-zone about 8$35 \mathrm{~mm}$ (Table 1). Among six bacterial isolates, 100\% isolates were found to inhibit S. aureus ATCC 25923 growth and $66.67 \%$ could inhibit C. albicans growth
(Figure 3), 33.33\% could inhibit E. coli ATCC 35218 growth and only $16.67 \%$ could inhibit B. subtilis FNCC 0060 growth, namely CRC32 isolate with the diameter of inhibition zone was $12 \mathrm{~mm}$ (moderate). The CRC32 isolate was the best isolate in inhibiting S. aureus ATCC 25923 growth with a diameter of inhibition zone was $26 \mathrm{~mm}$ (strong), while CRA8 isolate was the best isolate as an antiCandida with a diameter of inhibition zone $35 \mathrm{~mm}$ (strong).

\section{Phylogenetic tree analysis}

Based on phylogenetic tree analysis, the six bacteria isolates were divided into two branches. The first branch was the member of the PaenoBacillus genus and the second branch was the member of Bacillus genus (Figure 4). Figure 4 shows the phylogenetic tree generated after bootstrap 1000X validation and included Escherichia coli ATCC $11775 \mathrm{~T}$ as the outgroup. As many as four of six bacterial isolates belonging to the Bacillus spp. and two bacteria isolates including a member of Paenibacillus spp.

\section{Discussion}

Soil samples used in this study were taken from the rhizosphere of Cyperus rotundus in Cemoro Sewu Plateau, Magetan Regency, East Java, Indonesia at an altitude of 1920 meters above sea level. Bacterial isolates were obtained from a rarely explored site, unlike many studies that the isolates of antibiotic-producing microorganisms were largely obtained from marine and most of bacterial isolates were obtained from sponge. This study thus provides an alternative source for exploring antibioticproducing microorganism from the rhizosphere of $C$. rotundus grow in the highland.
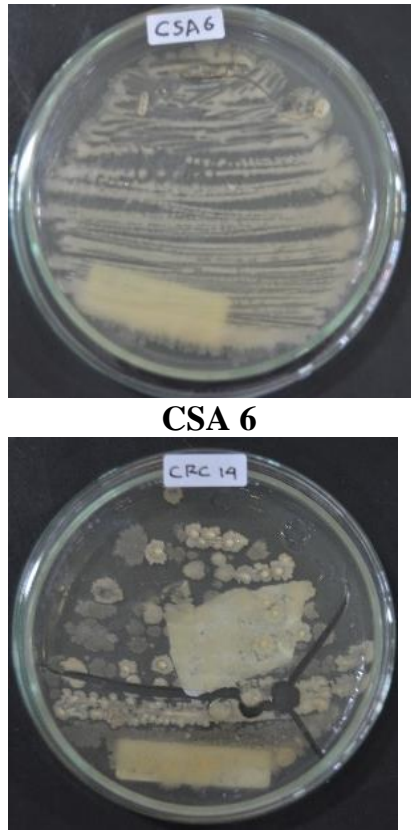

CRC 14

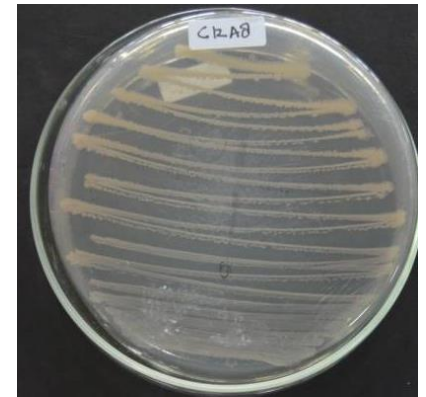

CRA 8

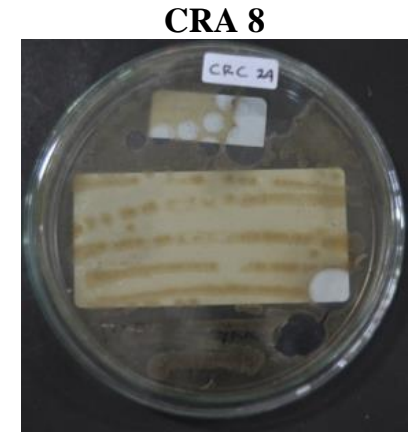

CRC 24

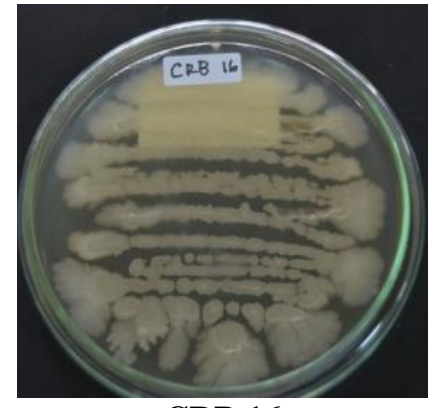

CRB 16

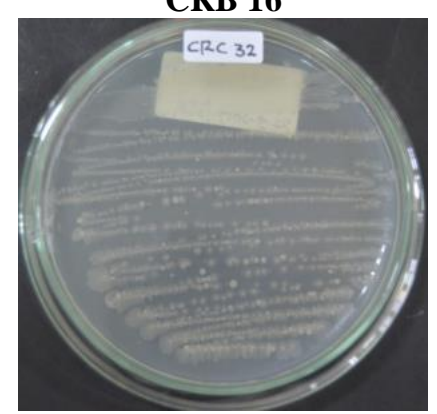

CRC 32

Figure 1. The results of purification of bacterial isolates isolated from the rhizosphere of Cyperus rotundus of Cemoro Sewu Plateau 


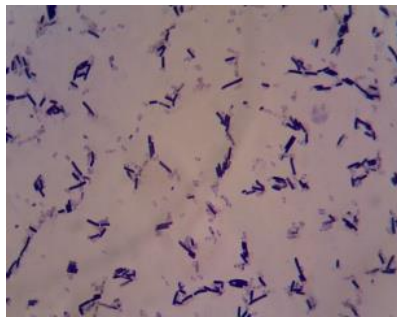

CSA 6

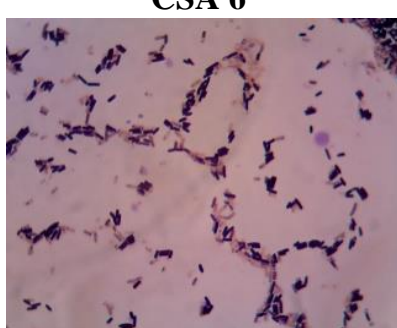

CRC 14

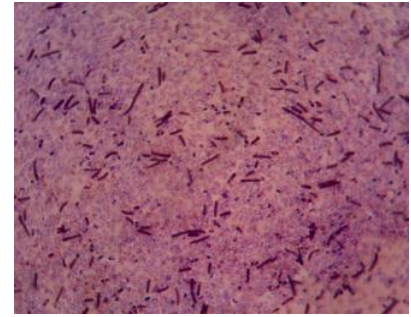

CRA 8

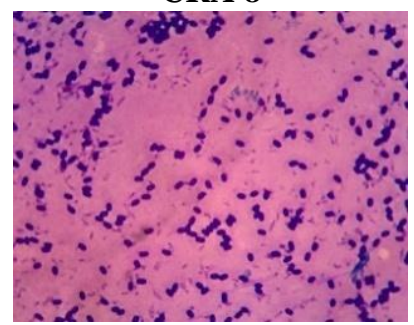

CRC 24

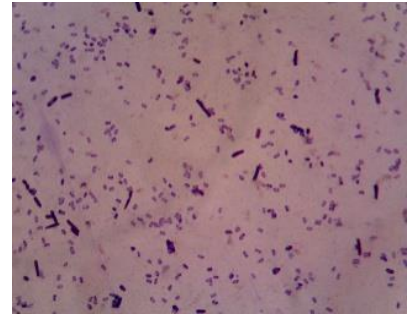

CRB 16

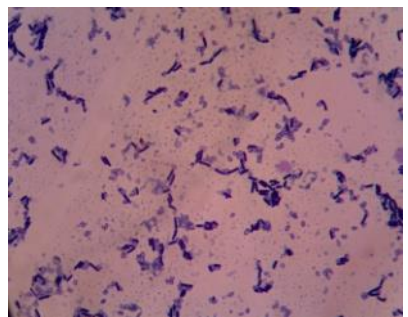

CRC 32

Figure 2. The results of Gram staining of bacterial isolates from the rhizosphere of Cyperus rotundus of Cemoro Sewu Plateau

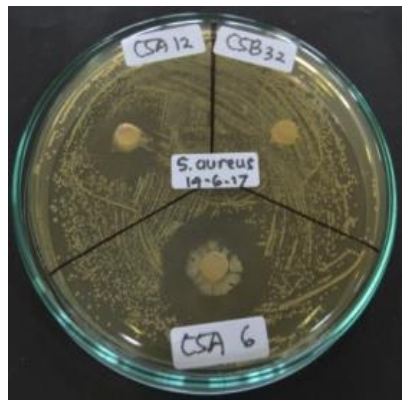

A

CSA 6

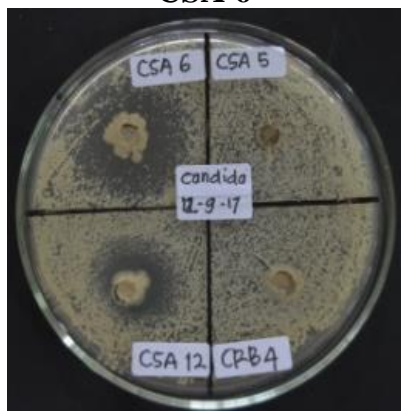

E

CSA 6

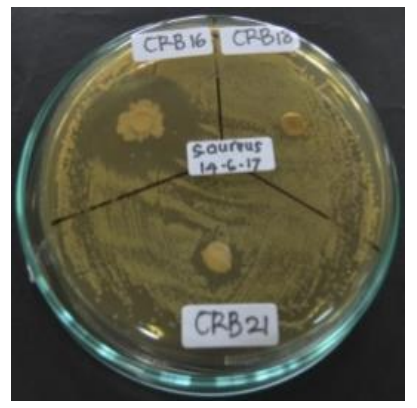

B

CRB 16

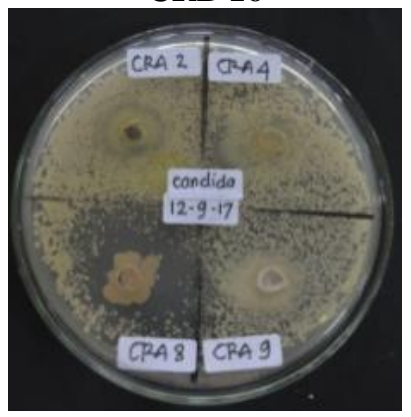

F

CRA 8

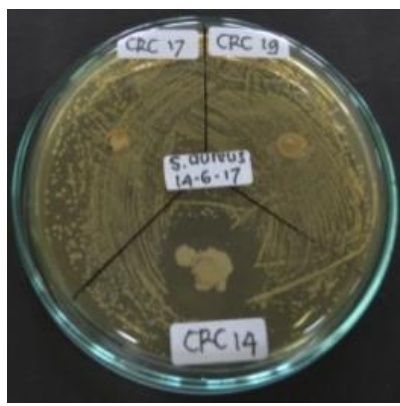

C

CRC 14

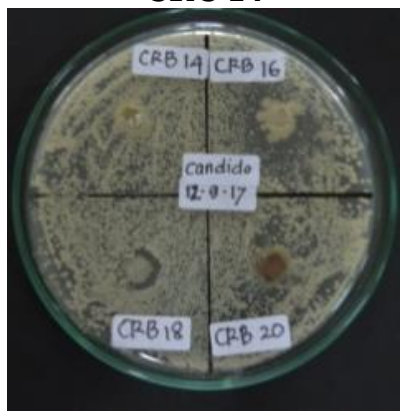

G

CRB 16

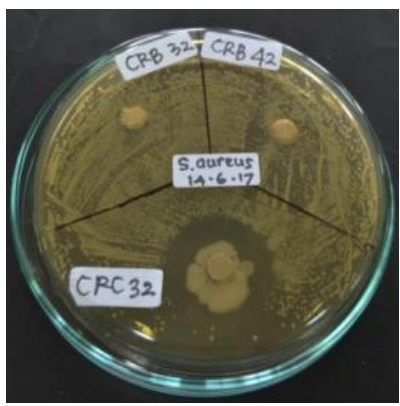

D

CRC 32

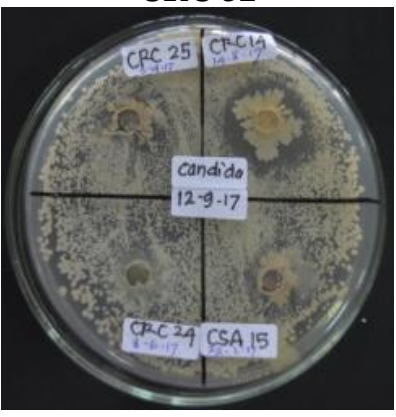

H

CRC 14

Figure 3. The results of antimicrobial activities of bacteria isolate isolated from the rhizosphere of Cyperus rotundus of Cemoro Sewu Plateau toward S. aureus ATCC 25923 and C. albicans. A: The inhibition of CSA6 isolate on S. aureus ATCC 25923, B: The inhibition of CRB16 isolate on $S$. aureus ATCC 25923, C: The inhibition of CRC14 isolate on S. aureus ATCC 25923, D: The inhibition of CRC32 isolate on $S$. aureus ATCC 25923, E: The inhibition of CSA6 isolate on $C$. albicans, F: The inhibition of CRA8 isolate on $C$. albicans, G: The inhibition of CRB16 isolate on C. albicans, H: The inhibition of CRC14 isolate on C. albicans

Highland site may impose extreme environmental conditions for the growth of microorganisms, including bacteria. The temperature in the Cemoro Sewu Plateau at the time of sampling reached $18.67^{\circ} \mathrm{C}$, relative humidity was $94 \%$ and light intensity was 348 lux. Such temperature can support the life of psychrophilic bacteria (growing at a temperature of $0-30^{\circ} \mathrm{C}$ ) and mesophilic bacteria $\left(15-55^{\circ} \mathrm{C}\right)$, despite the fact that both psychrophilic and mesophilic bacteria cannot grow optimally at this temperature as psychrophilic and mesophilic bacteria grow optimally at $15^{\circ} \mathrm{C}$ and $25-40^{\circ} \mathrm{C}$, respectively (Madigan et al. 2003). Relative humidity is also of significant factor in affecting bacterial growth. In general, bacteria will grow under relative humidity around $85 \%$ (Madigan et al. 2003), while 
the relative humidity at the sampling location was too high to support bacterial growth.

A total of six Gram-positive bacterial isolates have been obtained from the rarely explored site for isolating antibiotic-producing microorganisms (Figure 1 and Figure 2). Inhibition test against Staphylococcus aureus ATCC 25923 and Bacillus subtilis FNCC 0060 as the representative of Gram-positive bacteria, Escherichia coli ATCC 35218 as the representative of Gram-negative bacteria and Candida albicans as the representative of yeast have also been conducted. It was observed that the inhibition of Gram-positive bacteria, especially S. aureus, was stronger than that of Gram-negative bacteria (E. coli). It was also observed that only two isolates (CRB16 and CRC24) were found inhibited the growth of E. coli with 12 $\mathrm{mm}$ and $8 \mathrm{~mm}$ diameter of inhibition zone, respectively. In case of the inhibition of $S$. aureus, six isolates were found to be able to inhibit the growth of $S$. aureus with the largest diameter of the inhibition zone was $26 \mathrm{~mm}$ (CRC32). In addition, four isolates demonstrated strong anti-Candida capability as demonstrated by the wide inhibition zone of isolate CSA6 $(30 \mathrm{~mm})$ and CRA8 $(35 \mathrm{~mm})$. Interestingly, only one isolate (CRC32) was able to inhibit B. subtilis growth (Table 1 and Figure 3).

To determine the identity of the six bacterial isolates from Cemoro Sewu plateau, 16S rDNA sequencing was carried out. Sequence alignments' similarity by using BLAST showed that all of the six isolates were divided into two genera, Bacillus and Paenibacillus. The Bacillus includes two species, i.e. Bacillus subtilis and Bacillus amyloliquefaciens, while the Paenibacillus genus includes two species, namely Paenibacillus sonchi and Paenibacillus peoriae. More detailed data showed that the CSA6, CRB16 and CRC24 isolates were sister clade and they are identical to Bacillus subtilis JCM 1465 with a $99 \%, 100 \%$, and $99 \%$ similarity level respectively. The CRC14 isolate was the most similar to Bacillus amyloliquefaciens strain NBRC 15535 (99\%), while CRA8 isolate showed closest relationship with Paenibacillus sonchi strain X19-5 (97\%) and CRC32 isolate had a close relationship with Paenibacillus peroriae strain 3763 with a 99\% sequence similarities.

Table 1. The results of antimicrobial activities of bacteria isolate isolated from the rhizosphere of Cyperus rotundus of Cemoro Sewu Plateau

\begin{tabular}{|c|c|c|c|c|}
\hline \multirow{2}{*}{$\begin{array}{c}\text { Isolates } \\
\text { Code }\end{array}$} & \multicolumn{4}{|c|}{ Diameter of inhibition zone (mm) } \\
\hline & $\begin{array}{c}\text { S. aureus } \\
\text { ATCC } 25923\end{array}$ & $\begin{array}{c}\text { B. subtilis } \\
\text { FNCC 0060 }\end{array}$ & $\begin{array}{c}\text { E. coli } \\
\text { ATCC } 35218\end{array}$ & $\begin{array}{c}C . \\
\text { albicans }\end{array}$ \\
\hline$\overline{\text { CSA } 6}$ & 24 & - & - & 30 \\
\hline CRA 8 & 10 & - & - & 35 \\
\hline CRB 16 & 25 & - & 12 & 22 \\
\hline CRC 14 & 22 & - & - & 25 \\
\hline CRC 24 & 10 & - & 8 & - \\
\hline CRC 32 & 26 & 12 & - & - \\
\hline
\end{tabular}

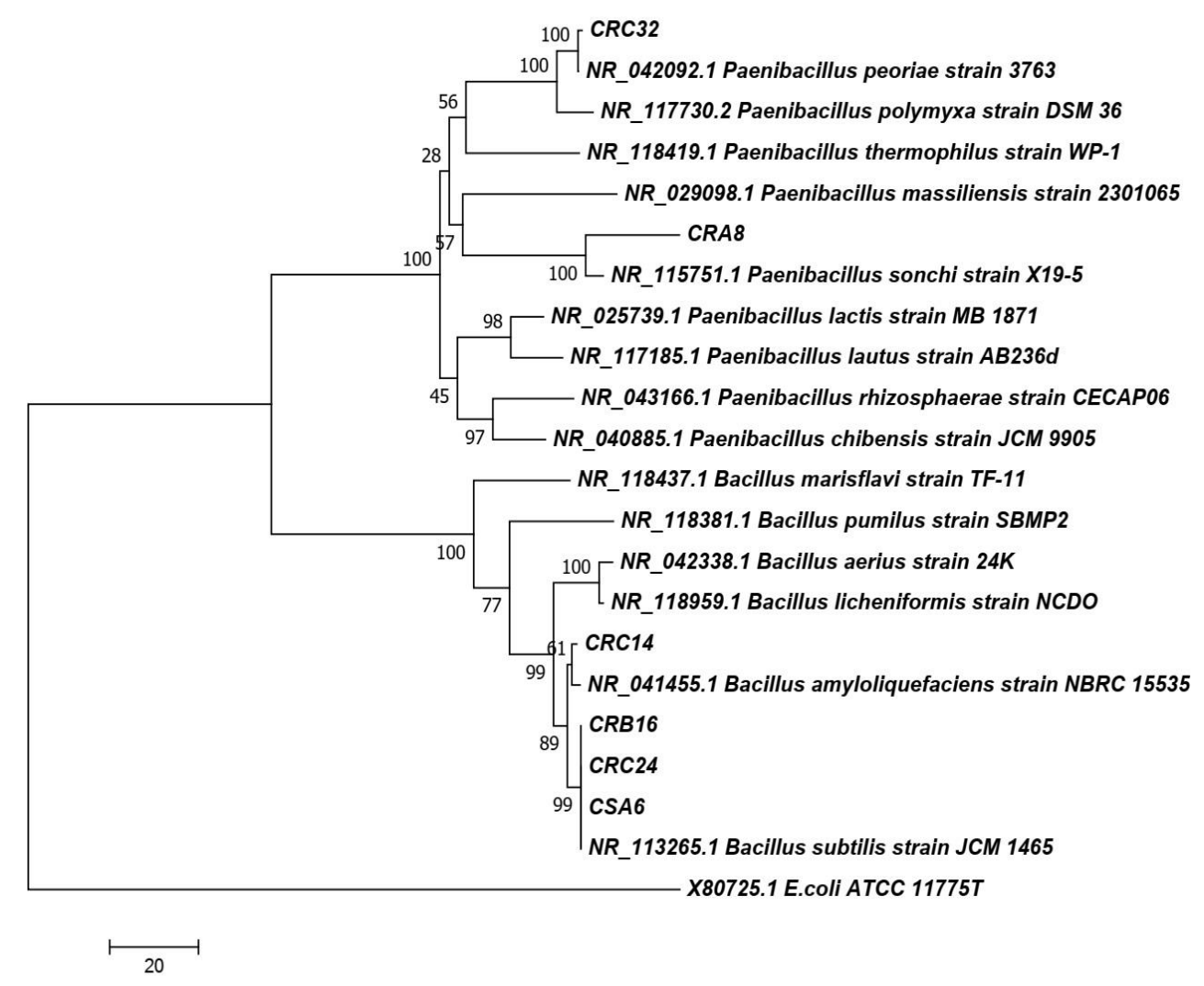

Figure 4. The neighbor-joining phylogenetic tree of bacterial isolates isolated from the rhizosphere of Cyperus rotundus of Cemoro Sewu Plateau based on 16S rDNA sequences 
Based on the measurements of inhibitory action against test organisms, the Bacillus isolates are more widely used as antimicrobial. The six isolates were shown capable of inhibiting the growth of $S$. aureus, four of which were the members of the Bacillus. Likewise, three isolates of Bacillus were also found to exhibit anti-Candida action which suppressed the growth of $C$. albicans. These results suggest that the Bacillus genus has a great potential in producing antimicrobial substances, including antibiotics. Some antibiotics have been produced by Bacillus spp. include subtilin, bacitracin, simplexin and bacillin (Foster and Woodruff 2010). Some studies also show that Bacillus spp. also, synthesize new compounds that have the potential as novel antibiotics. Thuricin 7 is the new bacteriocin produced by Bacillus thuringiensis BMG1.7 (Cherif et al. 2001). Two unidentified nonproteinaceous amino acids produced by the Bacillus subtilis strain of INA 01085 are also potential as new antibiotics (Malanicheva et al. 2014). Bacillus atrophaeus also produces new compounds that are different from bacitracin (Ebrahimipour et al. 2014).

Based on the level of inhibition, it was found that the inhibition on test organisms by isolates of Paenibacillus used in this study was greater than that of isolates belonging to the Bacillus genus. The CRC32 isolate (Paenibacillus peoriae strain 3763) had the strongest inhibitory action on $S$. aureus $(26 \mathrm{~mm})$, while CRA8 isolates (Paenibacillus sonchi strain X19-5) had the strongest inhibition to $C$. albicans $(35 \mathrm{~mm})$ growth. This results suggested that both members of the Bacillus and members of the Paenibacillus have the potential to produce antimicrobial substances. As of Bacillus spp, several studies also proved that Paenibacillus spp. also has the potential to produce antibiotics. Paenibacillus elgii B69 produces antibiotics pelgipeptin and polypeptin (Wu et al. 2010). The Paenibacillus polymyxa strain JSa-9 is capable of producing peptide antibiotics LI-F04a, LI-F04b and polymyxin $\mathrm{B}_{6}$ (Deng et al. 2011). Paenibacillus polymyxa PKBI produces various kinds of Polymyxin B-type antibiotics (Shaheen et al. 2011). Paenibacillus sp. also produces paenibacterin (Guo et al. 2012) and Paenibacillus sp. 530603 produces macrocyclic lipopeptidolactone, KB425796-A which has the potential as a novel antifungal (Kai et al. 2013).

Based on phylogenetic tree analysis (Figure 4) the six isolates is divided into two branches, one branch is a member of the Bacillus genus and the other branch is a member of the Paenibacillus genus. On one hand, CRC32 isolate is a sister clade to Paenibacillus peoriae strain 3763, while the CRA 8 isolate is a sister clade to Paenibacillus sonchi strain X19-5. Both isolates are in the Paenibacillus branch. However, the distance between CRA8 and Paenibacillus sonchi is farther than the distance between CRC32 and Paenibacillus peoriae, as evidenced by its level of similarity, in which of CRA 8 only has $97 \%$ similarity, and that the query level of CRA8 is only $97 \%$. Therefore, more in-depth study may reveal its identity as different strain or species. Paenibacillus sonchi strain X195 is a novel species of Paenibacillus genus isolated from the rhizosphere of Sonchus oleraceus and has the ability to fix nitrogen (Hong et al. 2009).

On the other hand, the third CSA6, CRB16, and CRC24 isolates are sister clade to Bacillus subtilis JCM 1465 strain, but the query level of CSA6 is only 97\%, despite the fact that it shows $99 \%$ similarity with Bacillus subtilis JCM 1465 strain. Further study may also reveal the identity of CSA6 as a new strain of Bacillus subtilis. Isolate CRC14 is a sister clade of Bacillus amyloliquefaciens strain NBRC 15535. Bacillus subtilis JCM 1465 and strain with Bacillus amyloliquefaciens strain NBRC 15535, are sister clades, therefore the relationship between the two is also close.

\section{ACKNOWLEDGEMENTS}

The authors would like to thank the Indonesian Ministry of Research, Technology and Higher Education, for providing research fund with "Hibah Disertasi Doktor" year 2017. We are also grateful to Muhammad Miftahussurur for his assistance in analyzing the $16 \mathrm{~S}$ rRNA gene sequence data.

\section{REFERENCES}

Abbas S, Senthilkumar R, Arjunan S. 2014. Isolation and molecular characterization of microorganisms producing novel antibiotics from soil sample. Euro J Exp Biol 4 (5): 149-155.

Altschul SF, Gish W, Miller W, Myers EW, Lipman DJ. 1990. Basic local alignment search tool. J Mol Biol 215: 403-410.

Amin A, Khan MA, Ehsanullah M, Haroon U, Azam SM, Hameed A. 2012. Production of peptide antibiotics by Bacillus sp. GU 057 indigenously isolated from saline soil. Braz J Microbiol 43 (4): 13401346. DOI: $10.1590 / \mathrm{S} 1517-838220120004000015$.

Arifuzzaman M, Khatun MR, Rahman H. 2010. Isolation and screening of Actinomycetes from Sundarbans soil for antibacterial activity. Afr J Biotechnol 9 (29): 4615-4619.

Asagabaldan MA, Ayuningrum D, Kristiana R, Sabdono A, Radjasa K, Trianto A. 2017. Identification and antibacterial activity of bacteria isolated from marine sponge Haliclona (Reniera) sp. against MultiDrug Resistant Human Pathogen. IOP Conf Ser Earth Environ Sci 55 (1): 012019. DOI:10.1088/1755-1315/55/1/012019.

Balcazar JL, Loureiro S, Silva YJD, Pintado J, Planas M. 2010. Identification and characterization of bacteria with antibacterial activities isolated from seahorses (Hippocampus guttulatus). J Antibiot 63: 271-274.

Chelossi E, Milanese M, Milano A, Pronzato R, Riccardi G. 2004. Caharacterisation and antimicrobial activity of epibiotic bacteria from Petrosia ficiformis (Porifera, Demospongiae). J Exp Mar Biol Ecol 309: 21-33.

Cherif A, Ouzari H, Daffonchio D, Cherif H, Ben SK, Hassen A, Jaoua S, Boudabous A. 2001. Thuricin 7: a novel bacteriocin produced by Bacillus thuringiensis BMG1.7, a new strain isolated from soil. J Appl Microbiol 32 (4): 243-247.

Cita YP, Suhermanto A, Radjasa OK, Sudharmono P. 2017. Antibacterial activities of marine bacteria isolated from sponge Xestospongia testudinaria from Sorong, Papua. Asian Pac. J Trop Biomed 7 (50): 450-454.

Deng Y, Lu Z, Bi H, Lu F, Zhang C, Bie X. 2011. Isolation and characterization of peptide antibiotics LI-F04 and Polymyxin B6 produced by Paenibacillus polymyxa strain Jsa-9. J Peptides 32 (9): 1917-1923.

Ebrahimipour GH, Khosravibabadi Z, Sadeghi H, Aliahmadi A. 2014. Isolation, partial purification and characterization of an antimicrobial compound, produced by Bacillus atrophaeus. Jundishapur J Microbiol 7 (9): e11802. DOI: 10.5812/jjm.11802. 
Fitri DS, Pangastuti A, Susilowati A, Sutarno. 2017. Endophytic bacteria producing antibacterial against methicillin-resistant Staphylococcus aureus (MRSA) in seagrass from Rote Ndao, East Nusa Tenggara, Indonesia. Biodiversitas 18 (2): 733-740. [Indonesian]

Florey HW. 1947. Antibiotics produced by bacteria. J Intern Med 128: 495-504.

Foster JW, Woodruff HB. 2010. Antibiotic substances produced by bacteria. Ann NY Acad Sci 12 (13): 125-136.

Gopi M, Kumaran S, Kumar TTA, Deivasigamani B, Alagappan K, Prasad SG. 2012. Antibacterial potential of sponge endosymbiont marine Enterobacter $\mathrm{sp}$ at Kavaratti Island, Lakshadweep archipelago. Asian Pac J Trop Med 5 (2): 142-146.

Guo Y, Huang E, Yuan C, Zhang L, Yousef E. 2012. Isolation of a Paenibacillus sp. strain and structural elucidation of its broadspectrum lipopeptide antibiotic. Appl Environ Microbiol 78 (9): 3156-3165.

Hong Y, Ma Y, Zhou Y, Gao F, Liu H, Chen S. 2009. Paenibacillus sonchi sp. nov., a nitrogen-fixing species isolated from the rhizosphere of Sonchus oleraceus. Intl J Syst Evol Microbiol 59: 2656-2661.

Kai H, Yamashita M, Takase S, Hashimoto M, Muramatsu H, Nakamura I, Yoshikawa K, Ezaki M, Nitta K, Watanabe M, Inamura N, Fujie A. 2013. KB425796-A, a novel antifungal antibiotic produced by Paenibacillus sp. 530603. J Antibiot 66: 465-471.

Kumar S, Stecher G, Tamura K. 2016. MEGA7: Molecular evolutionary genetics analysis version 7.0 for bigger datasets. Mol Biol Evol 33 (7): 1870-1874.

Lazzarini A, Cavaletti L, Toppo G, Marinelli F. 2000. Rare genera of Actinomycetes as potential producer of new antibiotics. Anton Leeuw Intl J G 78 (3-4): 399-405.

Madigan MT, Martinko JM, Parker J. 2003. Brock Biology of Microorganisms. 10th ed. Prentice-Hall, USA.

Magarvey NA, Keller JM, Bernan V, Dworkin M, Sherman DH. 2004 Isolation and characterization of novel marine-derivated Actinomycete taxa rich in bioactive metabolites. Appl Environ Microbiol 70 (12): 7520-7529.

Malanicheva IA, Kozlov DG, Efimenko TA, Zenkova VA, Kastrukha GS, Reznikova MI, Korolev AM, Borshchevskaia LN, Tarasova OD, Sineokiı̌ SP, Efremenkova OV. 2014. New antibiotics produced by Bacillus subtilis strains. Mikrobiologiia 83 (4): 445-450.

Mardhiana, Pradana AP, Adiwena M, Santoso D, Wijaya R, Murtilaksono A. 2017. Use of endophytic bacteria from roots of Cyperus rotundus for biocontrol of Meloidogyne incognita. Biodiversitas 18 (4): 13081315. [Indonesia]
Mohan G, Thangappanpillai AKT, Ramasamy B. 2016. Antimicrobial activities of secondary metabolites and phylogenetic study of sponge endosymbiotic bacteria, Bacillus sp. at agatti Island, Lakshadweep Archipelago. Biotechnol Rep 11: 44-52.

Nedialkova D, Naidenova M. 2005. Screening the antimicrobial activity of Actinomycetes strains isolated from Antarctica. J Cult Collect 4: 2935.

Nithya C, Pandian SK. 2010. Isolation of heterotrophic bacteria from Palk Bay sediments showing heavy metal tolerance and antibiotic production. Microbiol Res 165: 578-593.

Romanenko LA, Uchino M, Kalinovskaya NI, Mikhailov VV. 2008. Isolation, phylogenetic analysis and screening of marine molluscassociated bacteria for antimicrobial, hemolytic and surface activities. Microbiol Res 163: 633-644.

Saitou N, Nei M. 1987. The Neighbor-joining method: a new method for reconstructing phylogenetic trees. Mol Biol Evol 4 (4): 406-425.

Shaheen M, Li J, Ross AC, Vederas JC, Jensen SE. 2011. Paenibacillus polymyxa PKBI produces variants of polymyxin B-type antibiotics. Chem Biol 18 (12): 1640-1648.

Susilowati R, Sabdono A, Widowati I. 2015. Isolation and characterization of bacteria associated with brown algae Sargassum spp. from Pajang Island and their antibacterial activities. Prosedia Environ Sci 23: 240-246.

Thompson JD, Gibson TJ, Plewniak F, Jeanmougin F, Higgins DG. 1997. The CLUSTAL_X windows interface: flexiblee strategies for multiple sequence alignment aided by quality analysis tools. Nucleic Acids Res 25: 4876-4882.

Ullah I, Arshed M, Noureen U, Chaudhry MJI, Jadoon MA. 2010. Isolation of Streptomyces from the sediments of selected thermal springs of northern Pakistan and its intrinsic susceptibility and resistance. Rec Zool Surv Pak 21: 47-50.

Wilson GS, Raftos DA, Corrigan SL, Nair SV. 2010. Diversity and antimicrobial activities of surface-attached marine bacteria from Sydney Harbour, Australia. Microbiol Res J Intl 165: 300-311.

Wilson GS, Raftos DA, Nair S.V. 2011. Antimicrobial activity of surface attached marine bacteria in biofilm. Microbiol Res J Intl 166: 437448.

Wu X, Shen X, Ding R, Qian C, Fang H, Li O. 2010. Isolation and partial characterization of antibiotics produced by Paenibacillus elgii B69. FEMS Microbiol Lett 310: 32-38.

Zhao L, Xu Y, Lai X. 2018. Antagonistic endophytic bacteria associated with nodule of soybean (Glycine max L.) and plant growth-promoting properties. Braz J Microbiol 49 (2): 269-278. 